\title{
Performance of provitamin A- quality protein maize inbred lines and derived hybrids in contrasting environments
}

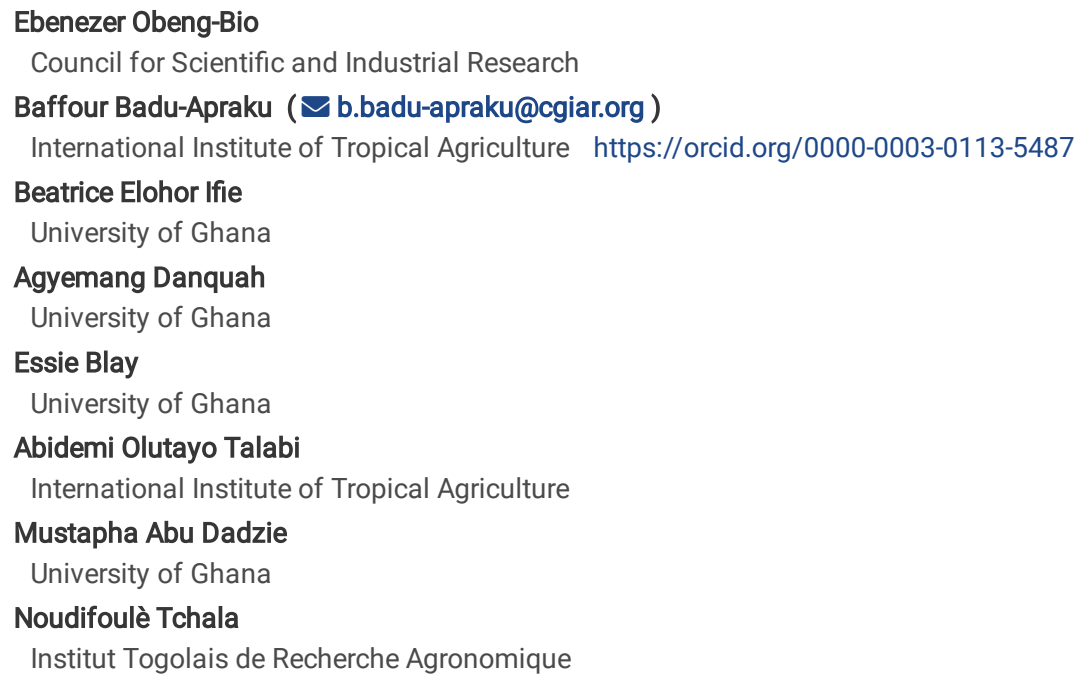




\section{Abstract}

Background Early maturing provitamin A (PVA) quality protein maize (QPM) inbred lines with tolerance to drought and low-N are needed to develop superior hybrids in West and Central Africa (WCA). This study aimed to (i) identify inbred lines that combined drought and low-N tolerance with increased levels of PVA and tryptophan and (ii) assess the relationship among PVA carotenoids, tryptophan and grain yield. Sixty-four inbred lines plus six inbred checks were evaluated under induced drought, low-N and optimal conditions in 2016 and 2017 in Nigeria. The inbred lines were assayed for PVA and tryptophan contents. Results Thirty-three of the lines were found to be tolerant to drought and low-N. Ninety percent of the inbred lines had tryptophan contents $>0.075 \%$ per sample in whole grain substantiating the presence of the QPM trait in the inbred lines. Inbred lines TZEIORQ 55 and TZEIORQ 29 combined high PVA contents (15.38 and $12.10 \mu \mathrm{g}$ g-1, respectively) with low-N tolerance while nine inbred lines combined moderate PVA levels (5.06 - 8.34 $\mu \mathrm{g} g-1)$ with drought and low-N tolerance. Conclusions These maize inbred lines could be utilized to develop superior drought and low- $\mathrm{N}$ tolerant hybrids and synthetics with elevated levels of PVA and tryptophan for WCA. The correlations observed among grain yield, PVA and tryptophan of the lines were not significant suggesting that these traits could be improved independently.

\section{Background}

Maize (Zea mays L.) production in West and Central Africa (WCA) is limited by major abiotic constraints including drought and poor soil fertility (particularly low- $\mathrm{N}$ ) which are the two most frequent yield reduction factors in the sub-region [1]. The occurrence of drought within the two weeks before and after flowering can lead to drastic grain yield losses of $40-90 \%$ [2]. Also, annual yield reduction in maize from the impact of low- $\mathrm{N}$ has been estimated to vary between 10 and $50 \%$ [3]. The frequent occurrence of drought and low-N on maize production fields in WCA contributes to low grain yield annually hovering around $1.8 \mathrm{t} / \mathrm{ha}$ [4]. The synergistic effect of the two stresses could even lead to total yield loss of maize [1]. However, studies have revealed that genetic improvement in maize under stress conditions could result in genetic gains under drought $[1,5,6]$ and under low- $\mathrm{N}[7,8,9]$. Assessing the efficiency of induced stress screening of advanced hybrid maize under drought and low-N for grain yield in favourable environments in Southern Africa, [10] showed that, for early maturing genotypes, indirect selection under low-N and optimal conditions was more efficient than direct selection under random abiotic stress. A similar report was found for indirect selection under induced drought. However, direct selection was most efficient for predicting performance under low-N conditions.

Vitamin A, an essential micronutrient, is needed by human beings for improved vision, skin health and enhanced immune system, especially, in infants. However, vitamin A cannot be synthesised by human beings and its requirements must be met through external sources. [11] revealed that inadequate supply of vitamin-A causes weak immune system and increases the risk of child mortality resulting from communicable diseases and disorders. Unfortunately, the

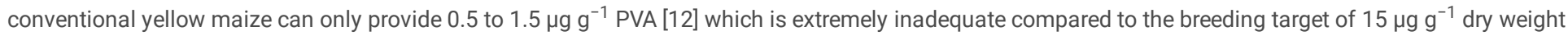
established by the HarvestPlus Challenge program [13] to prevent vitamin A deficiency (VAD) in diets dominated by maize. The PVA maize could provide more than $15 \mu \mathrm{gg}^{-1}$ dry weight of PVA to combat VAD and its health-related problems including night blindness and depressed immune response [14]. Maize $\beta$ carotene was more effective when PVA maize was consumed as a staple food and could avoid the potential of hypervitaminosis A that could occur with the utilization of preformed vitamin A supplementation [15].

The conventional maize grain has a major shortfall as food or feed because the protein lacks adequate levels of tryptophan and lysine which are the two amino acids responsible for the quality differences between QPM and conventional maize. As a result, heavy reliance on conventional maize by infants with less protein supplement could predispose them to childhood disorders such as "kwashiorkor" (a fatal condition emanating from initial growth failure). Conversely, quality protein maize (QPM) has the potential to provide more than double the contents of tryptophan and lysine to prevent protein energy malnutrition. The QPM is capable of supplying about $73 \%$ of the protein required by humans as compared with about $46 \%$ obtainable in conventional maize [16]. [17] found that the protein of QPM contains about $80 \%$ biological value (a measure of protein absorption in human beings) relative to $40-57 \%$ of conventional maize. Consumption of QPM resulted in a $12 \%$ increase in the rate of growth in weight and a $9 \%$ increase in the rate of growth in height of a mild to moderately malnourished infant population [18].

In view of the greater potential of maize for drought and low-N tolerance as well as accumulation of elevated levels of PVA, tryptophan and lysine in its endosperm, there is the need to develop maize hybrids that combine tolerance to drought and low- $\mathrm{N}$ with increased contents of PVA, tryptophan and lysine to ensure food and nutrient security in WCA. In response to this need, the IITA-maize improvement program has between 2007 and 2015 , developed inbred lines with varying reactions to drought and low-N stresses and also biofortified for PVA and tryptophan. This was necessary because successful performance of maize hybrids both under stress and favourable growing conditions largely depends on the genetic potentials of their parental lines especially when the inbred lines combine superior performance for important traits that are highly heritable [19]. However, in the course of the inbreeding program, the inbred lines were screened based on visual observation to select for kernels with deep orange colour for the PVA trait, and the endosperms with opaqueness ranging from 25 $50 \%$ for the QPM trait. Also, stay-green characteristic (STGR), anthesis-silking interval (ASI), plant and ear aspects (PASP and EASP) and number of ears per plant (EPP) have strong associations with grain yield (GY) especially, under stressful environments. Therefore, these traits have been successfully employed in a multiple-trait base index (MI) to select superior maize genotypes [1, 20]. It was, therefore, important to evaluate the recently developed early maturing PVAQPM inbred lines for superior performance under stressful (drought and low- $\mathrm{N}$ ) and non-stressful environments and also investigate the levels of PVA and tryptophan using chemical analysis to establish the basis for developing drought and low-N tolerant PVA-QPM hybrids and synthetics. This study aimed at (i) identifying inbred lines that combined drought and low-N tolerance with increased contents of PVA and tryptophan, (ii) assess the relationship among PVA, tryptophan and grain yield of the inbred lines under favourable growing conditions, (iii) determine the inbred-hybrid relationships under the contrasting environments and (iv) examine grain yield performance of hybrids derived from selected outstanding inbred lines in hybrid combinations.

\section{Results}


The ANOVA under two managed drought conditions revealed significant $(P<0.01)$ variation among environments $(E)$ and inbreds $(G)$ except ASI, PASP, EASP and EPP for environments. However, inbred $x$ environment interactions (GEI) were significant $(P<0.05)$ for only GY and ASI (Table 1$)$. Repeatability $(R)$ estimates based on plot means obtained for GY was $58 \%$ under drought. Across the three low-N environments, the combined ANOVA showed significant (P < 0.01) variations among $E, G$ and GEl mean squares for the traits measured except GEl mean squares for ear height (EHT) (Table 1). Estimates of R ranged from $18 \%$ for PASP to $63 \%$ for DA (days to $50 \%$ anthesis) with GY recording $42 \%$. Under optimal environments, the ANOVA showed significant ( $P<0.05$ ) differences among E, G and GEI mean squares for all traits measured and the few exceptions were GEI mean squares for DA, plant height (PLHT) and EASP (Table 2). Estimates of Rranged from $52 \%$ for EPP to $87 \%$ for DA. High Restimate of $58 \%$ was recorded for GY. Across the eight test environments, the observed differences among $E, G$, research condition and GEI mean squares for the traits measured were statistically significant $(P<0.01)$ except GEI mean squares for DA (Table 2). Although the interactions between mean squares of $G$ and research condition was not significant for the major response variable (GY), significant variations were detected for other important traits, notably, ASI, EASP and STGR. Across environments, ASI recorded the lowest R estimate (18\%) while the highest (83\%) was observed for PLHT. A relatively high $\mathrm{R}^{2}$ estimate of $56 \%$ was obtained for GY.

Grain yield of the inbreds under drought conditions varied from $100 \mathrm{~kg} \mathrm{ha}^{-1}$ for TZEIORQ 41 to $895 \mathrm{~kg} \mathrm{ha}^{-1}$ for TZEIORQ 8 with a mean of $321 \mathrm{~kg}^{-1}$ (Table 3). Comparison of the GY under drought to that under non-stress conditions revealed high variation in yield reductions of $25 \%$ for TZEIORQ 8 to $94 \%$ for TZEIORQ 11 with a mean of $76 \%$. Averages of ASI and STGR under drought were 4.27 and 4.51 respectively. Under low-N environments, GY of the inbreds varied from $299 \mathrm{~kg} \mathrm{ha}^{-1}$ for TZEQI 85 to $1652 \mathrm{~kg} \mathrm{ha}^{-1}$ for TZEIORQ 12 with a mean of $980 \mathrm{~kg} \mathrm{ha}^{-1}$ (Table 3). Grain yield reduction due to the effects of the low-N ranged from $8 \%$ for TZEIORQ 48 to $82 \%$ for TZEQI 85 with a mean of $35 \%$. The inbreds recorded greater yield reductions under drought than under low-N conditions. Averages of ASI and STGR under low-N were 1.07 and 3.49 respectively. The combined data across test environments showed a wide variation in GY from 394 $\mathrm{kg} \mathrm{ha}^{-1}$ for TZEQI 74 to $1307 \mathrm{~kg} \mathrm{ha}^{-1}$ for TZEIORQ 27 with an average of $942 \mathrm{~kg} \mathrm{ha}^{-1}$. Grain yield reduction across drought and low-N environments ranged from $18 \%$ for TZEIORQ 8 to $87 \%$ for TZEQI 85 with a mean of $56 \%$. Generally, from the performance across stress environments, the inbred lines that recorded increased ASI, higher STGR and high percentage GY reduction also had lower GY and negative selection indices (Table 3).

Under drought, 46\% (32 out of 70) of the inbred lines recorded positive base indices indicating drought tolerance, 53\% (37) of the inbreds assessed under low$\mathrm{N}$ conditions had positive base indices, indicating low-N tolerance, 16 inbreds showed tolerance to drought and low- $\mathrm{N}$ simultaneously while 33 inbreds showed tolerance across stress environments using the multiple trait base index with performance under optimal conditions serving as a check (Additional file 1 ).

Most of the measured traits exhibited significant $(P<0.05)$ genetic correlations with GY (Additional file 2). Grain yield recorded highly significant $(P<0.01)$ negative correlations with PASP and EASP under each and across environments. However, GY had highly significant $(P<0.01)$ and negative correlation coefficients with ASI, and STGR under drought but not under low-N conditions. Under drought, ASI exhibited highly significant positive genetic correlations with PASP (0.98), EASP (0.98) and STGR (0.86) but displayed highly significant negative correlations with ears per plant (-0.98) as well as plant height (-0.98). Ear aspect consistently displayed significant $(P<0.05)$ positive correlations with the flowering traits including $D A$, days to $50 \%$ silking $(D S)$ and $A S I$ under each and across environments.

The ANOVA for carotenoids and tryptophan revealed significant $(P<0.01)$ variation among the early PVA-QPM inbreds, except for a-carotene (Additional file 3). However, no significant differences were detected among the lines for kernel colour. The effects of replications were not significant for most carotenoids except for $\beta$-cryptoxanthin and $\beta$-carotene. Estimated PVA contents of inbred lines varied from $3.47 \mu \mathrm{g} \mathrm{g}^{-1}$ for TZEIORQ 48 to $15.38 \mu \mathrm{g} \mathrm{g}^{-1}$ for TZEIORQ 55 with a mean of $6.47 \mu \mathrm{g} \mathrm{g}^{-1}$ (Table 4). The levels of the three PVA carotenoids ranged from 1.15 to $6.61 \mu \mathrm{g} \mathrm{g}^{-1}$ with an average of $2.88 \mu \mathrm{g} \mathrm{g}{ }^{-1}$ for $\beta$-cryptoxanthin, from 0.45 to $2.10 \mu \mathrm{g} \mathrm{g}^{-1}$ with an average of $0.99 \mu \mathrm{g} \mathrm{g}^{-1}$ for a-carotene, and from 2.18 to $11.23 \mu \mathrm{g} \mathrm{g}^{-1}$ with an average of $4.52 \mu \mathrm{g} \mathrm{g}{ }^{-1}$ for $\beta$-carotene. Relative to the other carotenoid contents, the a-carotene levels of the selected inbred lines were very low. Kernel colour scores of the inbred lines varied from 7.0 (moderately deep yellow) to 10.0 (dark orange) with a mean of 7.84 . Ninety-five percent of the inbred lines had $>0.075 \%$ tryptophan per sample in whole grain. "Obatanpa", the standard QPM check, recorded the highest level of tryptophan and was 37\% higher than the second best inbred, TZEIORQ 42 . Ten out of the 19 selected inbred lines assayed were tolerant to drought, while 11 including TZEIORQ 29 and TZEIORQ 55 which recorded PVA contents of 12.10 and $15.38 \mu \mathrm{g} \mathrm{g}{ }^{-1}$ were tolerant to low-N environments. Also, ten inbred lines displayed combined drought and low-N tolerance out of the 19 inbred lines across drought, low-N and optimal environments (Table 4).

Highly significant $(P<0.01)$ positive phenotypic correlations were observed among PVA and its component carotenoids including $\beta$-cryptoxanthin $(r=0.75)$, $a-$ carotene $(r=0.67)$ and $\beta$-carotene $(r=0.93)$ (Table 5). Significant $(P<0.05)$ and positive correlations were also observed between PVA and total carotenoids $(r$ $=0.73$ ) as well as kernel colour $(r=0.52)$, but the correlations between PVA and the non-PVA carotenoids, lutein and zeaxanthin, were not significant. The correlations among grain yield and the nutritional traits were not significant for the selected inbred lines except for $\beta$-cryptoxanthin and zeaxanthin. The highest significant $(P<0.01)$ correlation coefficient was found between PVA and $\beta$-carotene $(r=0.93)$, followed by the correlation between $\beta$-cryptoxanthin and a-carotene $(r=0.77)$.

The 100 hybrids including four commercial hybrid checks evaluated showed varying degrees of drought and low-N tolerance. The 20 best performing hybrids including two commercial hybrid checks (Table 6) were identified using the multiple trait base index (MI). Although the best commercial hybrid check, TZEI 124 x TZEI 25 was outstanding under optimal conditions it suffered significant grain yield penalties under drought and low- $\mathrm{N}$ conditions. The best hybrid check was therefore ranked $11^{\text {th }}$ according to the MI across the two stress environments. On the other hand, as many as seven of the top performing hybrids including TZEIORQ 40 x TZEIORQ 26, TZEIORQ 26 x TZEIORQ 47, TZEIORQ 42 x TZEIORQ 20, TZEIORQ 20 x TZEIORQ 45, TZEIORQ 29 x TZEIORQ 43,

TZEIORQ 48 x TZEIORQ 43 and TZEIORQ 29 x TZEIORQ 24 significantly outperformed the best commercial check, TZEI $124 \times$ TZEI 25 across drought and low$\mathrm{N}$ conditions. Moreover, the yields of these top performing hybrids were statistically equal to the best check and also recorded relatively lower percentage grain yield reductions compared to the best check. 
The correlation between mid-parent values of inbred lines and the means of measured traits of the hybrids were significant for grain yield, plant and ear heights, plant and ear aspects, ears per plant and stay green characteristic under drought (Table 7). Under low-N and across environments, the inbred-hybrid relationship was significant for grain yield, days to $50 \%$ anthesis and silking, plant and ear heights, plant and ear aspects and stay green characteristic. Also, under optimal environments, mid-parent values of inbred lines had significant correlations with means of measured traits of the hybrids for grain yield, days to $50 \%$ anthesis and silking, plant height, and plant aspect. Furthermore, grain yield recorded significant positive average heterosis of $513,237,235$ and $315 \%$ under drought, low-N, optimal and across environments respectively. Similarly, plant and ear heights had highly significant positive heterosis under each and across research environments. Significant negative heterosis was observed for days to $50 \%$ anthesis and silking under drought, low- $\mathrm{N}$, optimal and across environments, while anthesis-silking interval recorded significant negative heterosis under drought. Highly significant positive heterotic values were obtained for ear aspect and ears per plant under drought environments.

\section{Discussion}

The significant variation $(P<0.01)$ observed among $G, E$, and GEl for grain yield and most of the traits measured under each and across test environments implied the existence of genetic variability in the early maturing PVA-QPM inbred lines. The significance of E and GEI observed for GY and several other traits under each and across environments suggested the inconsistent rankings of the traits measured in varying environments and that inbred evaluations in more environments was necessary to identify outstanding genotypes as reported in other studies under drought $[1,6,16]$ and under low-N [21].

The high R estimates recorded for PASP, EASP, EPP and STGR compared with the relatively moderate R estimate for GY under drought indicated that R estimates of GY under drought could be low and that it is important to use the yield related traits (with high R) to complement GY in the identification of drought tolerant inbred lines [1,22]. This result was supported by the highly significant negative genetic correlation coefficients observed between GY and PASP, EASP and STGR, and the highly significant and positive association recorded between GY and EPP. However, the very low R estimate (< 0.30$)$ obtained for ASI among the inbred lines under drought contradicted the findings of earlier workers [22,23] who identified ASI as a reliable secondary trait for selecting drought tolerant maize cultivars. Nonetheless, a highly significant and negative genetic correlation was found between ASI and GY under the contrasting environments suggesting that R of GY and other adaptive traits and their genetic correlations were important components to guide breeding strategies in the improvement of the early PVA-QPM inbred lines.

The high repeatability estimates recorded for GY, DA, DS, PLHT and EHT under low-N indicated that early generation testing of the inbred lines using these traits under low-N conditions would be successful as reported by $[7,8]$. However, among these traits, DA was the only trait which recorded significant genetic correlation with GY, indicating that it was the most reliable trait that complemented GY under low-N conditions. Similarly, the strong genetic correlations of PASP and EASP with GY under low-N suggested the high probability of these yield related traits being reliable under low-N. This result agreed with the report of [24], who identified PASP and EASP as reliable traits for improving GY under low-N using a set of extra-early maize genotypes. The unreliability of EPP to complement GY under low-N corroborated the results of [25] who detected EPP as an unpredictable trait in selecting for improved GY in low soil N conditions. This result also revealed that STGR is more reliable than ASI for selection for GY in limited soil N conditions. The high R values observed for the six agronomic traits (except ASI) employed in the combined drought and low-N multiple-trait index and their strong genetic associations with GY across test environments confirmed the reliability of those traits in selecting inbred lines tolerant to limited water and nitrogen availability.

Under optimal environments, the very high repeatability estimates recorded for DA, DS, PLHT and EASP compared to that of GY underscored the need to select for these secondary traits in early generations to improve GY. The 32 out of the 70 inbred lines identified as drought tolerant based on the drought base index would serve as an important source of drought tolerant genes for developing superior drought tolerant hybrids [19], synthetics and for the improvement of the early PVA-QPM inbred lines to tolerate drought. Similarly, the 37 low-N tolerant inbred lines identified in this study would be invaluable for the exploitation of low- $\mathrm{N}$ tolerant genes to develop superior hybrids and synthetic varieties under limited nitrogen environments [9, 21]. Moreover, the 33 inbred lines (47\% of 70 ) identified as drought and low-N tolerant based on the multiple-trait base index underscored the earlier finding that similar adaptive mechanisms were involved in the tolerance to the two stresses and that selection under drought could also indirectly result in improved low-N tolerance as reported by several authors [7, $21,24]$.

The PVA contents of the selected inbred lines assayed which ranged from 3.47 to $15.38 \mu \mathrm{g} \mathrm{g}^{-1}$ with an average of $6.47 \mu \mathrm{g} \mathrm{g} \mathrm{g}^{-1}$ indicated the existence of significant variability for the PVA carotenoids in the inbred lines used [26,27]. This range of PVA values exceeded the 5.00 to $7.80 \mu \mathrm{g} \mathrm{g}^{-1}$ reported by [28] for 15 tropically adapted yellow maize inbred lines, but was comparable to the 0.06 to $17.25 \mu \mathrm{g} \mathrm{g}^{-1}$ with an average of $5.87 \mu \mathrm{g} \mathrm{g} \mathrm{g}^{-1}$ reported by [29] for 130 intermediate/late maturing PVA inbred lines. However, only TZEIORQ 55 recorded a PVA value comparable to the $15 \mu \mathrm{g} \mathrm{g}{ }^{-1}$ which is the current breeding target set by HarvestPlus Challenge Program [13,30,31]. Although these results have signalled the potential of meeting the set target using this inbred set, there is the need to introgress the best favourable alleles of PVA from other germplasm sources into the tropically adapted inbred lines to speed-up the development of high PVA hybrids adapted to limited moisture and nitrogen conditions. The highest estimated mean of total carotenoids was $60.22 \mu \mathrm{g}{ }^{-1}$ which was higher than the $42.71 \mu \mathrm{g} \mathrm{g}^{-1}$ obtained by [29] but was far below the $100 \mu \mathrm{g} \mathrm{g}^{-1}$ reported by [32]. The significance of high total carotenoids is that inbred lines harbouring higher contents of total carotenoids could serve as invaluable sources of the PVA carotenoids especially if the influx of assimilates to the carotenoid biosynthetic pathway favours the build-up of the PVA in the endosperm. The results of the present study revealed relatively higher levels of lutein and zeaxanthin (synthesized from the PVA carotenoids) at the expense of the PVA carotenoids for most of the inbred lines. This result corroborated the findings of [33] who identified lutein and zeaxanthin as the most predominant carotenoids in the maize endosperm. These results however, contradicted the findings of [34] who found many genotypes having high PVA contents (ranging from 15 to $20 \mu \mathrm{g} \mathrm{g}^{-1}$ ) comparable to the non-PVA carotenoids when improved PVA inbred lines and populations were assayed. 
Ninety percent of the inbred lines had tryptophan contents $>0.075 \%$ per sample in whole grain and thus, the lines met the quality standards of a QPM genotype as reported by $[35,36]$. However, new sources of PVA genes would be necessary to improve the existing early maturing PVA-QPM inbred lines to speed-up the process of developing high PVA maize hybrids for commercialization in SSA to combat "hidden hunger" due to VAD. The two inbred lines, TZEIORQ 55 and TZEIORQ 29 identified as possessing high levels of PVA (15.38 and 12.10 $\mathrm{g} \mathrm{g} \mathrm{g}^{-1}$, respectively) and low-N tolerance could be invaluable sources of PVA genes for the improvement of the early PVA-QPM source population and for the development of PVA-QPM inbred lines, hybrids and synthetics with tolerance to the two stresses. Furthermore, multiple stress tolerant extra-early maize inbred lines with PVA levels higher than the target of 15 ug/g established by the HarvestPlus Challenge Program have been identified in IITA [37]. The extra-early (80-85 days to physiological maturity) inbred lines, TZEEIOR 202 and TZEEIOR 205 have $22.58 \mathrm{ug} \mathrm{g}^{-1}$ and $23.98 \mathrm{ug} \mathrm{g}^{-1}$, respectively. These normal endosperm PVA inbred lines could be invaluable sources of high PVA genes for developing high PVA-QPM early maturing inbred lines through introgression of the favourable PVA alleles into tropical early maturing PVAQPM source populations and extracted inbred lines. The lack of significant correlations among GY, PVA and tryptophan suggested that the individual traits could be readily improved simultaneously. A different result was earlier reported by [14] who found higher levels of tryptophan to be associated with PVA levels in the PVA-QPM varieties evaluated. Moreover, the non-significant correlations observed between PVA and lutein as well as zeaxanthin indicated that the contents of the PVA carotenoids could be improved without significant negative association with the synthesis of lutein and zeaxanthin which are by-products in the PVA biosynthetic pathway. Furthermore, the weak positive and significant correlations observed between kernel colour and PVA, and $\beta$-carotene suggested that to some extent, the intensity of the orange colour of kernels could be a quick (but not the most reliable) approach to identifying inbred lines with high PVA levels. In contrast, [29] reported non-significant correlations between kernel colour and PVA as well as $\beta$-carotene contents in the set of intermediate and late inbred lines studied. The differences in the results of the two studies may be attributed to the differences in the germplasm used in the two different studies.

An important objective of the present study was to compare the grain yield performance of the two most outstanding hybrid checks, TZEI $124 \times$ TZEI 25 and TZEIOR $127 \times$ TZEIOR 57 with the performance of the PVA-QPM hybrids derived from the outstanding drought and low $\mathrm{N}$ tolerant inbred lines identified in the present study. This was important for the assessment of the level of heterosis among the early maturing PVA-QPM inbred lines since they were all extracted from the same QPM-PVA variety. It was striking that seven of the top performing hybrids, TZEIORQ $40 \times$ TZEIORQ 26, TZEIORQ 26 x TZEIORQ 47, TZEIORQ 42 x TZEIORQ 20, TZEIORQ 20 x TZEIORQ 45, TZEIORQ 29 x TZEIORQ 43, TZEIORQ 48 x TZEIORQ 43 and TZEIORQ 29 x TZEIORQ 24 significantly out-yielded the most outstanding commercial check, TZEI 124 x TZEI 25 across drought and low-N conditions. It was worth noting that the six inbred lines TZEIORQ 40, TZEIORQ 26, TZEIORQ 20, TZEIORQ 29, TZEIORQ 48 and TZEIORQ 24 identified among the best performing inbred lines were involved in the best hybrid combinations. This observation demonstrated that the outstanding performance of the hybrids under varying environments was attributable largely to the superior performance of the PVA-QPM inbred lines for important agronomic traits [19]. The most outstanding commercial hybrid check, TZEI $124 \mathrm{x}$ TZEI 25, was released and commercialized in Mali in 2014 as Tamalaka, in Nigeria in 2014 as Sammaz 41 and in Ghana in 2015 as CSIR- Denbea [16]. This result implied that, the seven best hybrids would be the hybrids of choice under drought prone and nitrogen deficient environments in West and Central Africa.

Assessment of the relationship between hybrids and their parental lines for grain yield and other important agronomic traits under drought, low- $\mathrm{N}$ and optimal environments was necessary to ascertain the possible improvement in those traits of the hybrids under each and across environments based on the performance of parents. The significant correlations recorded between mid-parent values and the means of the corresponding hybrids for grain yield, plant height, ear aspect and stay-green characteristic under drought, low- $\mathrm{N}$, optimal and across environments suggested that initial screening and selection of drought and low-N tolerant inbred lines for the development of superior hybrids would be effective. The significant but weak correlation observed between midparent values and means of hybrids for grain yield under low-N and optimal environments indicated the need for using secondary traits to support grain yield in predicting hybrid performance based on their parents under low- $\mathrm{N}$ and optimal conditions. This result corroborated the findings of [21]. However, the result is not entirely consistent with the report by [19] who observed significant and strong correlation between mid-parent and hybrid means under low- $\mathrm{N}$ but a weak correlation under optimal conditions. On the other hand, the non-significant correlations between parental lines and their hybrids for ears per plant under low- $\mathrm{N}$ and optimal conditions suggested that predicting hybrid performance based on prolificacy may not be effective under low- $\mathrm{N}$ and optimal environments. Similar result was reported by [38] under optimal environments. The inconsistencies in the results of the different studies could be attributed to the different parental inbred lines used as well as the levels of inbreeding [21]. The highly significant positive heterosis observed for grain yield, plant height and ear height under drought, low-N, optimal and across test environments indicated that there was high potential for the exploitation of superior hybrid performance to increase grain yield under each and across test environments. This result, coupled with the significant negative heterosis observed for days to $50 \%$ anthesis and silking under each and across environments implied that the hybrids matured faster than their parents, produced taller and more vigorous plants which translated into high grain yield. Similar results were reported by [39] under optimal conditions and [21] under low-N conditions.

\section{Conclusions}

Thirty-three of the inbred lines assessed were found to be tolerant to drought and low-N. Ninety percent of the inbred lines had tryptophan contents $>0.075 \%$ per sample in whole grain indicating that most of the lines possessed the quality protein trait. However, low to moderate levels of PVA were recorded for most of the inbred lines including those tolerant to the two stresses. This result suggested the need to introgress favourable PVA alleles from the recently identified extra-early inbred lines, TZEEIOR 202 and TZEEIOR 205 (with PVA levels of 22.58 and 23.98 ug g $^{-1}$, respectively) into the early PVA-QPM inbred lines. These two inbred lines are also multiple stress tolerant (combined tolerance to drought and low $\mathrm{N}$ and resistant to Striga) and therefore their exploitation could accelerate progress in developing high PVA-QPM hybrids adapted to the stressful drought and low-N conditions in WCA. Furthermore, inbred lines TZEIORQ 55 and TZEIORQ 29 combined high PVA contents (15.38 and 12.10 $\mathrm{g} \mathrm{g}^{-1}$ respectively) with low-N tolerance while nine inbred lines combined moderate PVA levels $\left(5.06-8.34 \mu \mathrm{g} \mathrm{g}^{-1}\right)$ with drought and low-N tolerance. These inbred lines could also be important sources of PVA beneficial alleles for improvement of the early PVA-QPM inbred lines from which drought and low-N tolerant PVA-QPM hybrids and synthetics could be developed. The lack of significant correlations observed among grain yield, PVA and tryptophan suggested that these traits could be readily improved independently without significant trade-offs. The superior performance of the identified hybrids, the significant correlation between mid-parent values and their hybrids, as well as the significant average

Page 5/17 
heterosis observed for grain yield and other important agronomic traits under each and across stress environments suggested the existence of adequate genetic variability within the early maturing PVA-QPM inbred lines. Thus, the inbred lines could be exploited for the development of superior early maturing PVA-QPM drought and low-N tolerant hybrids and synthetics.

\section{Methods}

Genetic materials

The inbred lines were extracted from the early maturing PVA-QPM variety, 2009 TZE - OR2 DT STR QPM. The background of this variety is highly diverse with its development commencing in 2007 by crossing a drought and Striga resistant early QPM variety, TZE-Y-Pop-DT-STR-QPM with an intermediate maturing (105-110 days to maturity) high PVA maize [Syn-KU1409/DES/1409-(OR2)] from the IITA-MIP to introgress genes for high $\beta$-carotene into the QPM variety. This was followed by one cycle of backcrossing to the recurrent parent for recovery of earliness. In 2008, the $\mathrm{BC}_{1} \mathrm{~F}_{1}$ lines with deep orange colour (for $\mathrm{PVA}$ ) and/or appropriate endosperm modifications were selected and advanced to the $F_{2}$ and the $F_{3}$ generations. In 2009, the $F_{3}$ lines were selected based on their reactions to Striga, drought and low-N, and recombined to constitute the early PVA-QPM variety, 2009 TZE-OR2-DT-STR-QPM. From 2011 to 2014, another program was initiated to extract the first generation of early maturing inbred lines from the PVA-QPM variety and the $\mathrm{S}_{1}$ lines were advanced using the pedigree method to $\mathrm{S}_{6}$ generation. In 2015, a set of 73 early maturing PVA-QPM inbreds were selected based on the orange colour and opaqueness of the kernels [16]. Sixty-four of these inbred lines plus six inbred checks were evaluated in this study. Four out of the six checks, TZEQI 85, TZEQI 91, TZEQI 74 and TZEQI 82 are early maturing, yellow, QPM inbred lines, while the remaining two, TZEI 129 and TZEI 24 are early maturing, normal endosperm yellow inbred lines. These checks were used because early maturing PVA QPM inbred checks were not available. Furthermore, 24 outstanding inbred lines identified on the basis of their reactions to drought and low-N stresses (after one-year inbred evaluations) were grouped into six sets with each set containing four inbreds and used to generate 96 early maturing PVA-QPM single-cross hybrids at IITA, Ibadan, Nigeria. Each inbred line served as a female parent in one set and a male parent in another according to the North Carolina Design 2 mating scheme [40]. The PVA-QPM single-cross hybrids plus 4 commercial hybrid checks were evaluated across drought, low-N and optimal environments in Nigeria for two years.

Field trials

Evaluations of the 70 inbred-lines were carried out under managed drought, low- $\mathrm{N}$ and optimal conditions in 2016 and 2017 while the hybrid evaluations were conducted in 2017 and 2018 in Nigeria. The managed drought experiments were conducted at Ikenne $\left(6^{\circ} 50^{\prime} \mathrm{N}, 30^{\circ} 45^{\prime} \mathrm{E}, 62 \mathrm{~m}\right.$ altitude, $1200 \mathrm{~mm}$ mean rainfall annually) in the $2016 / 2017$ and $2017 / 2018$ dry seasons. Drought stress was achieved by supplying 17 mm of sprinkler irrigation water in a week up to 25 days after planting (DAP) after which the irrigation was terminated and the maize plants depended on the available soil moisture to reach physiological maturity. The managed drought trials received NPK fertilizer at the rate of $60 \mathrm{~kg} \mathrm{ha}^{-1}$ each of N, P and K (15-15-15) during planting. Additionally, top dressing was done with $60 \mathrm{~kg} \mathrm{ha}^{-1}$ of $\mathrm{N}$ (supplied as urea) at 3 weeks-after-planting (WAP).

Evaluations of the inbred-lines under low- $\mathrm{N}\left(30-\mathrm{kg} \mathrm{ha}^{-1}\right)$ conditions were carried out at lle-lfe-(7 30' N, $531^{\prime} \mathrm{E}$, and $240 \mathrm{~m}$ altitude, $1250 \mathrm{~mm}$ mean rainfall

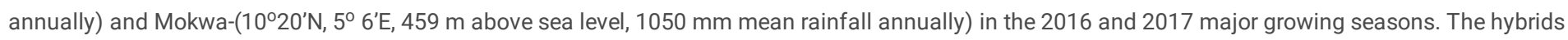
were also evaluated in an adjacent field in 2017 and 2018 major seasons. According to [41], the Mokwa topsoil is a luvisol while that of Ile-lfe is Alfisol. Low soil $\mathrm{N}$ conditions at both locations were accomplished by depleting the fields of $\mathrm{N}$ through continuous cultivation of densely populated maize without fertilizer application for 3 cropping seasons and complete removal of all crop residues at the end of every harvest. Prior to field preparation, topsoil samples were collected at the depth of $0-15 \mathrm{~cm}$ for analysis of the contents of nitrogen $(\mathrm{N})$, phosphorus $(\mathrm{P})$ and potassium (K) using the Kjeldahl digestion and colorimetric procedure [42] at the IITA analytical services laboratory, lbadan, Nigeria. The low-N experimental field at Mokwa had $0.085 \%(\mathrm{~N}), 6.32 \mathrm{ppm}(\mathrm{P})$ and $0.20 \mathrm{cmol} \mathrm{kg}^{-1}(\mathrm{~K})$, whereas that of Ile-lfe contained $0.084 \%(\mathrm{~N}) ,2.05 \mathrm{ppm}(\mathrm{P})$ and $0.358 \mathrm{cmol} \mathrm{kg}^{-1}(\mathrm{~K})$. Based on the soil tests, NPK fertilizer was formulated using urea ( $\mathrm{N}$ source), triple superphosphate $\left(\mathrm{P}_{2} \mathrm{O}_{5}\right.$ source) and muriate of potash $\left(\mathrm{K}_{2} \mathrm{O}\right.$ source), respectively, and it was applied immediately after thinning (2 WAP). The urea provided a basal available $\mathrm{N}$ of $15 \mathrm{~kg} \mathrm{ha}^{-1}, \mathrm{P}_{2} \mathrm{O}_{5}$ and $\mathrm{K}_{2} \mathrm{O}$ fertilizers supplied $60 \mathrm{~kg} \mathrm{ha}^{-1}$ each of $\mathrm{P}$ and $\mathrm{K}$. Additionally, top dressing of $15 \mathrm{~kg}$ $\mathrm{ha}^{-1}$ of $\mathrm{N}$ (supplied as urea) was done at 4 WAP to bring the total available $\mathrm{N}$ received on the low-N fields to $30 \mathrm{~kg} \mathrm{ha}^{-1}$.

The inbred trials under favourable growing conditions were planted at Mokwa, Ikenne and lle-lfe in the 2016 and 2017 rainy seasons, while the hybrids were planted in the 2017 and 2018 major seasons. The optimal trials received NPK (15:15:15) fertilizer at $60 \mathrm{~kg} \mathrm{ha}^{-1}$ each for N, P and Kat 2 WAP immediately after thinning. Top dressing was done at 4 WAP with additional $30 \mathrm{~kg} \mathrm{~N} \mathrm{ha}^{-1}$. In all the experiments, $7 \times 10$ and $10 \times 10$ randomized incomplete-block designs were used for the inbreds and the hybrids respectively, with two replications in each case. The experimental units consisted of $3 \mathrm{~m}$ long one-row plots with a spacing of $0.75 \times 0.40 \mathrm{~m}$. Three seeds were sown per hill and later, seedlings were thinned to two at 2 WAP to give a population density of about 66,667 plants $\mathrm{ha}^{-1}$. Weeds were managed in all trials by the application of pre- and post- emergence herbicides, atrazine (primextra) and gramozone (paraquat) respectively, each at the rate of 5 litres ha ${ }^{-1}$.

Data collection

Based on individual plots for inbred lines and hybrids, data were taken for DA and DS as well as PLHT and EHT. PASP and EASP were rated on a scale of 1-9 ( $1=$ excellent plants or ears and $9=$ extremely poor plants or ears). The difference between DA and DS was calculated as ASI. EPP was obtained as the ratio of the number of harvested ears in a plot to the total number of plants in that plot. At 70 DAP, visual ratings for STGR were carried out for the trials under managed drought and low-N using a scale of 1-9 (1= less than $10 \%$ dead leaf area and $9=$ more than $80 \%$ dead leaf area). The harvested ears from each plot under the two stress conditions were shelled and grain weight was measured. Grain moisture content was determined using Kett moisture tester PM-450Grain 
weight was adjusted to $15 \%$ moisture content, and $\mathrm{GY}$ in $\mathrm{kg} \mathrm{ha}^{-1}$ was computed on plot basis. For the optimal trials on the other hand, an assumption of $80 \%$ shelling percentage was considered per plot to compute GY from ear weight adjusted to $15 \%$ moisture content.

Production of inbred kernel samples for carotenoid and tryptophan analyses

Nineteen inbred lines with good agronomic performance were selected and planted under well-watered growing conditions in January 2018 at IITA Ibadan, to produce fresh kernel samples for carotenoid and tryptophan analyses. The inbred lines were planted in $1 \mathrm{~m}$ long single row plots with a spacing of $0.75 \mathrm{x} 0.20$ $\mathrm{m}$. Two seeds were sown per hill and subsequently thinned to one to provide at least 5 plants per inbred line. Kernel samples for analyses of maize carotenoids were produced by selfing all plants in a plot. Harvested ears of the self-pollinated inbred lines in each plot were well-dried at room temperature ( $12 \%$ moisture content) and shelled separately (individual ears from an inbred line). Equal number of kernels were taken from each ear to form a bulk representative sample per inbred line. One hundred seeds were drawn for carotenoid and tryptophan analyses in the Food and Nutritional Laboratory of IITA, Ibadan. In addition, kernel colour was scored following the standard colour scale for determining total carotenoid content [43], and this was converted to a scale of 1 to 12 representing shades of colours from pale yellow to darkest orange as observed within the early maturing PVA-QPM inbred line set evaluated.

Quantification of PVA carotenoids and tryptophan

Carotenoids were extracted and quantified by High Performance Liquid Chromatography at the Food and Nutritional Laboratory of IITA, Ibadan, Nigeria. The protocol for extraction and the method of carotenoid analysis employed were based on the procedure described by [44]. Total carotenoids were computed as the total of a-carotene, $\beta$-carotene, $\beta$-cryptoxanthin, zeaxanthin and lutein concentrations. The PVA was derived by adding the value of $\beta$-carotene, and $50 \%$ each of the concentrations of $\beta$-cryptoxanthin and $\alpha$-carotene, since $\beta$-cryptoxanthin and $\alpha$-carotene contribute half each of the amount of $\beta$-carotene as PVA [45]. Values of PVA and other carotenoid levels of each sample were obtained from two independent measurements to allow for statistical analysis.

The selected early maturing PVA-QPM inbred lines plus an intermediate maturing open-pollinated QPM variety standard check "Obatanpa" were analysed for only tryptophan content but not lysine or both in endosperm flour. This is because lysine content of the maize endosperm is highly correlated with that of tryptophan (greater than 0.9$)[46,47]$. Moreover, analysis for tryptophan is far cheaper than lysine and so it is economically prudent for the breeder to use tryptophan content to determine the nutritional potential of QPM genotypes at early breeding stages. Estimated levels of tryptophan were obtained by the colorimetric technique as described by [48]. Levels of tryptophan were quantified with the aid of a standard curve of a well-known check. Tryptophan content for each sample was obtained from two independent measurements to allow for data analysis.

Data analysis

Agronomic data recorded for the inbreds and hybrids under each environment were subjected to analysis of variance (ANOVA) separately with PROC GLM (the general linear model procedure) in SAS including a random statement and a test option [49]. A combined ANOVA was later performed across all environments. Location by year combination was considered as an environment whereas the managed drought, low- $\mathrm{N}$ and favourable growing environments represented research conditions. Environments, replications within environments and also incomplete blocks within replications $\times$ environment interactions were treated as random factors and the inbreds and hybrids were regarded as a fixed factor. The model used to reflect the layout of the experiments was as follows:

\section{$y k l j m i=\mu i+E k i+R(E) k l j i+G m i+G E k m i+\epsilon k l j m i$}

Where $Y_{k I m i}$ is the measurement of trait i with mean effect $\mu \mathrm{i}, E_{k i}$ is the environmental effect $\mathrm{k}$ on trait $\mathrm{i}, R B(E)_{k l j i}$ represents the effect of replicates I and block j within environment $\mathrm{k}$ on trait $\mathrm{i}, G_{m i}$ is the genotypic effect $\mathrm{m}$ on trait $\mathrm{i}, G E_{k m i}$ is the genotype $\mathrm{m} \times$ environment $\mathrm{k}$ interaction effect on trait i, and $\epsilon_{k l j m i}$ represents the effect of experimental error due to genotype $\mathrm{m}$, replicates I and block j within environment $k$ on trait i. Significant differences among means were assessed using standard error of a difference. Genetic and phenotypic variance components of the inbred lines were estimated under each and across research conditions with the restricted maximum likelihood (REML) method using PROC Varcomp in SAS to compute the repeatability (R) for each of the traits measured using the formula;

$R=\sigma g 2 \sigma g 2+\sigma g e 2 e+\sigma 2 r e$

where $\sigma \mathrm{g} 2$ is the additive genetic variance (since the genetic materials are inbred lines) [50], $\sigma \mathrm{g}$ e 2 is the variance of genotype $\times$ environment interaction, $\sigma 2$ is the experimental error variance, e represents the environments while $r$ is the replications per environment. Furthermore, the relationship between grain yield and the other agronomic traits measured under each and across environments were examined by estimating the genetic correlation coefficients for each pair of traits using the meta menus program in SAS [49]. Drought and low-N tolerant inbred lines and hybrids were identified using the MI proposed by [1]. Grain yield (GY), number of ears per plant (EPP), ASI, plant aspect (PASP), ear aspect (EASP) and stay-green characteristic (STGR) were employed to compute the MI as follows;

$M . I=[2 \times G Y+E P P-A S I-P A S P-E A S P-S T G R$

To reduce the effects of differences in scales/units of measurements, each of the parameters was standardized using a standard deviation of 1 and a mean of zero. Positive MI values indicated drought or low N tolerance while negative values implied susceptibility. Also, the MI was applied to data across drought and low-N environments to assess the combined reactions of the inbred lines to the two stresses. In addition, data for PVA carotenoids and tryptophan of the inbred lines were subjected to ANOVA in SAS and means were separated using standard error (SE). Phenotypic correlations between PVA and other carotenoids, kernel colour, tryptophan, and grain yield were estimated to assess the relationships among the traits. Phenotypic correlation coefficients were computed using the Spearman rank correlation method in SAS. 
Furthermore, for the agronomic traits, mid-parent values for a cross was computed as the mean of the two parental lines averaged for each research conditions, and across all research conditions. The relationship between per se performance of the parental lines and the grain yield of their respective hybrids under each and across research conditions was estimated using Spearman's rank correlation analysis implemented in SAS. Thus, the correlation coefficient of traits of parental lines with grain yield of their hybrids were calculated using mean grain yields of hybrids and the corresponding mid-parent values. Also, the percent increase or decrease of $F_{1}$ hybrids over mid parent values was calculated to estimate possible heterotic effects for the measured traits [51]. Values for mid-parent heterosis (MPH) for a cross were computed for each trait as follows:

\section{MP H = F $1-M P M P \times 100$}

Where;

$F_{1}=$ Mean of the hybrid,

MP = the mean of the parents that constituted the hybrids.

Mid-parent heterosis were averaged separately under drought, low- $\mathrm{N}$, optimal and across all the twelve test environments. T-test was performed to determine whether $F_{1}$ hybrid means were statistically different from mid parent means as follows [52].

$\mathrm{tij}=\mathrm{F} 1 \mathrm{ij}-\mathrm{MP} 38 \mathrm{EMS}$

Where;

$\mathrm{F}_{1} \mathrm{ij}=$ The mean of the $\mathrm{ij}^{\text {th }} \mathrm{F}_{1}$ cross

MPij = The mid parent for the $\mathrm{ij}^{\text {th }}$ cross

EMS $=$ Error mean square

\section{List Of Abbreviations}

ANOVA, analysis of variance; ASI, anthesis-silking interval; DA, days to 50\% anthesis; DAP, days after planting; DS, days to $50 \%$ silking; E, environment; EASP, ear aspect; EPP, number of ears per plant; G, inbred; GEl, inbred x environment interaction; GY, grain yield; IITA, International Institute of Tropical Agriculture; MI, multiple-trait base index; PASP, plant aspect; PVA, Provitamin A; QPM, quality protein maize; SE, standard error; VAD, vitamin A deficiency; WAP, Weeks after planting; WCA, West and Central Africa.

\section{Declarations}

\section{Ethics approval and consent to participate}

Not applicable

\section{Consent for publication}

Not applicable

\section{Availability of data and material}

The datasets used and/or analysed during the current study are available from the corresponding author on reasonable request.

\section{Competing interests}

The authors declare that the research was conducted in the absence of any commercial or financial relationships that could be construed as a potential conflict of interest.

\section{Funding}

This research was conducted through funding support from Alliance for a Green Revolution in Africa under West Africa Center for Crop Improvement of University of Ghana, Legon- Accra and co-funding from United States Agency for International Development under Norman E. Borlaug Leadership Enhancement in Agriculture Program Fellowship and Bill and Melinda Gates foundation under the Drought Tolerant Maize for Africa Project of IITA and the Stress Tolerant Maize for Africa Project.

\section{Authors' contributions}


EO and BB conceived, designed and executed the experiment as well as drafted the manuscript; EO, AT and NT analysed the data, executed the experiment and drafted the manuscript; El, AD, EB and MD critically reviewed the manuscript. All contributing authors agreed to the final version of the manuscript.

\section{Acknowledgements}

The authors are grateful to the USAID and West Africa Center for Crop Improvement (WACCI) for the financial support in the conduct of this study. We are also grateful to the Bill and Melinda Gates Foundation for the funding support through the DTMA/STMA Project and the staff of the IITA Maize Improvement Program and the Food and Nutrition Laboratory in Ibadan, Nigeria, for the technical assistance.

\section{References}

Badu-Apraku B, Fakorede MAB, Oyekunle M, Akinwale RO. Selection of extra-early maize inbreds under low $\mathrm{N}$ and drought at flowering and grain-filling for hybrid production. Maydica. 2011; 56: 1721-1735.

Menkir A, Akintunde AO. Evaluation of the performance of maize hybrids, improved open pollinated and farmers' local varieties under well-watered and drought stress conditions. Maydica. 2001; 46: 227-238.

Wolfe DW, Henderson DW, Hsiao TC, Alvio A. Interactive water and nitrogen effects on maize. II Photosynthetic decline and longevity of individual leaves. Agronomy Journal 1988;80: 865- 870.

FAOSTAT Food and Agriculture Organization of the United Nations Database, 2016. Accessed on 18 ${ }^{\text {th }}$ March, 2018.

Badu-Apraku B, Ifie BE, Talabi AO, Obeng-Bio E, Asiedu R. Genetic variances and heritabilities of traits of an early yellow maize population after cycles of improvement for Striga resistance and drought tolerance. Crop Sci. 2018;58:1-13 https://doi.org/10.2135/cropsci2017.10.0628.

Edmeades GO, Bolaños J, Chapman SC, Lafitte HR, Bänziger M. "Selection Improves Drought Tolerance in Tropical Maize Populations: In. Gains in Biomass, Grain Yield, and Harvest Index." Crop Sci.1999; 39:1306-15.

Bänziger M, Edmeades GO, Lafitte HR. Selection for drought tolerance increases maize yields over a range of N levels. Crop Sci. 1999; 39:1035-1040.

Badu-Apraku B, Oyekunle M, Akinwale RO, Aderounmu M. Combining ability and genetic diversity of extra-early white maize inbreds under stress and nonstress environments. Crop Sci 2013; 53: 9-26.

Ifie BE, Badu-Apraku B, Gracen V, Danquah EY. Genetic analysis of grain yield of IITA and CIMMYT early-maturing maize inbreds under Striga-infested and lowsoil nitrogen environments. Crop Sci. 2015; 55:610-623

Weber VS, Melchinger AE, Magorokosho C, Makumbi D, Bänziger M, Atlin GN. Efficiency of Managed-Stress Screening of Elite Maize Hybrids under Drought and Low Nitrogen for Yield under Rainfed Conditions in Southern Africa. Crop Sci. 2012; 52(3), 1011. https://doi.org/10.2135/cropsci2011.09.0486.

Rice AL, West KP, Black RE. Vitamin A deficiency. In: M. Ezzati, A.D. Lopez, A. Rodgers, and C.J.L. Murray, editors, Comparative quantification of health risks: Global and regional burden of disease attributable to selected major risk factors. Vol. 1. World Health Organization, Geneva. $2004: 211-256$.

Egesel CO, Wong JC, Lambert RJ Rocheford TR. Combining ability of maize inbreds for carotenoids tocopherols. Crop Sci. 2003; 43:818-823.

Harvestplus. Micronutrient malnutrition. Vitamin A. Fifth report on the world nutrition situation, UN SCN, March 2004. Available at: http://www.harvestplus. org/content/ vitamin. Accessed August 24, 2018.

Pixley K, Rojas NN, Babu R, Mutale R, Surles R, Simpungwe E. Biofortification of maize with provitamin A carotenoids. In Carotenoids hum heal SE- 17. Edited by Tanumihardjo SA. LA- English: Humana Press; 2013: 271-292.

Gannon B, Kaliwile C, Arscott SA, Schmaelzle S, Chileshe J, Kalungwana N, Mosonda M, Pixley K, Masi C, Tanumihardjo SA. Biofortified orange maize is as efficacious as a vitamin A supplement in Zambian children even in the presence of high liver reserves of vitamin A: a community-based, randomized placebocontrolled trial. The American Journal of Clinical Nutrition, 2014;100(6):1541-1550. https://doi.org/10.3945/ajcn.114.087379.

Badu-Apraku B, Fakorede MAB. Genotype by environment interaction: Advances in Genetic Enhancement of Early and Extra-early Maize for Sub-Saharan Africa; 2017. Book chapter (17), Springer.

Bressani R. Nutritional value of high lysine maize in human. In: E.T. Mertz, Quality Protein Maize. American Association of Cereal Chemists, St Paul, Minnesota USA; 1992:205-224.

Gunaratna NS, Groote HD, Nestel P, Pixley KV McCabe GP. A meta-analysis of community-based studies on quality protein maize. Food Policy 2010; 35(3): 202-210. https://doi.org/10.1016/j.foodpol.2009.11.003.

Betrán J, Beck D, Bänziger M, Edmeades GO. Genetic analysis of inbred and hybrid grain yield under stress and non-stress environments in tropical maize. Crop Sci. 2003 43: 807-817.

Bänziger M, Lafitte HR. Efficiency of secondary traits for improving maize for low-nitrogen target environments. Crop Sci.1997; 37:1110-1117. 
Meseka SK, Menkir A, Ibrahim AES, Ajala SO. Genetic analysis of performance of maize inbred lines selected for tolerance to drought under low nitrogen. Maydica. 2006; 51: 487-495.

Bänziger M, Edmeades GO, Beck D, Bellon M. Breeding for Drought and Nitrogen Stress Tolerance in Maize: From Theory to Practice. Mexico, D.F CIMMYT: 2000.

Badu-Apraku B, Fakorede MAB, Gedil M, Annor B, Talabi AO, Akaogu IC, Oyekunle M, Akinwale RO, Fasanmade TY. Heterotic patterns of IITA and CIMMYT earlymaturing yellow maize inbreds under contrasting environments. Agronomy Journal 2016; 108: 1-16.

Badu-Apraku B, Akinwale RO, Franco J, Oyekunle M. Assessment of reliability of secondary traits in selecting for improved grain yield in drought and lownitrogen environments. Crop Sci. 2012; 52: 2050-2062.

Lafitte HR, Edmeades GO. Improvement for tolerance to low soil nitrogen in tropical maize I. Selection criteria. Field Crops Res. 1994; 39 (1): 1-14.

Pfeiffer WH, McClaffert B. HarvestPlus: breeding crops for better nutrition. Crop Sci. 2007; 47: S88-S105.

Mishra P, Singh NK. Spectrophotometric and TLC based characterization of kernel carotenoids in short duration maize. Maydica 2010; (55) 95-100.

Menkir A, Liu W, White WS, Maziya-Dixon B, Rocheford T. Carotenoid diversity in tropical-adapted yellow maize inbred lines. Food Chem. 2008; 109 : 521-529.

Azmach G, Gedil M, Menkir A, Spillane C. Marker-trait association analysis of functional gene markers for provitamin A levels across diverse tropical yellow maize inbred lines. BMC Plant Biology 2008;13(1): 227. https://doi.org/10.1186/ 1471-2229-13-227.

Ortiz-Monasterio JI, Palacios-Rojas N, Meng E, Pixley K, Trethowan R, Pena RJ. Enhancing the mineral and vitamin content of wheat and maize through plant breeding. J Cereal Sci. 2007; 46:293-307.

Harjes CE, Rocheford TR, Bai L, Brutnell TP, Kandianis CB, Sowinski SG, Buckler ES. Natural genetic variation in lycopene epsilon cyclase tapped for maize biofortification, Science 2008; 319: 330-333.

Burt AJ, Grainger CM, Smid MP, Shelp BJ, Lee EA. Allele mining of exotic maize germplasm to enhance macular carotenoids. Crop Sci. 2011; 51:991-1004.

Howitt CA, Pogson BJ. Carotenoid accumulation and function in seeds and non-green tissues. Plant, Cell and Environment, 2006; 29(3):435-445.

https://doi.org/10. 1111/j.1365-3040.2005.01492.x.

Babu R, Rojas NP, Gao S, Yan J, Pixley K. Validation of the effects of molecular marker polymorphisms in LcyE and CrtRB1 on provitamin A concentrations for 26 tropical maize populations. Theor. Appl. Genet. 2012; 126:389-399.

Vivek BS, Krivanek AF, Palacios-Rojas N, Twumasi-Afriyie S, Diallo AO. Breeding quality protein maize (QPM): Protocols for developing QPM cultivars. CIMMYT. 2008.

Teklewold A, Wegary D, Tadesse A, Tadesse B, Bantte K, Friesen D, Prasanna BM. Quality Protein Maize (QPM): A Guide to the Technology and Its Promotion in Ethiopia. CIMMYT: Addis Ababa, Ethiopia. 2015.

Badu-Apraku B, Talabi A, Gedil M, Garcia-Oliveira AL. IITA scientists develop multiple stress tolerant maize hybrids with high levels of Pro-Vitamin A. IITABulletin 2019:2463. Available at http://bulletin.iita.org/index.php/2019/01/07/iita-scientists-develop-multiple-stress-tolerant-maize-hybrids-with-high-levels-ofpro-vitamin-a. Accessed on January 9, 2019.

Oyekunle M, Badu-Apraku B. Genetic analysis of grain yield and other traits of early-maturing maize inbreds under drought and well-watered conditions. Journal of Agron. and Crop Sci. 2013; 200(2): 92-107. https://doi.org/10.1111/jac.12049.

Ofori AP, Ofori K, Obeng-Antwi K, Tengan ML, Badu-Apraku B. Combining ability and heterosis estimate of extra-early quality protein maize (QPM) single cross hybrids. Journal of Plant Breeding and Crop Sci. 2015; 7(4): 87-93.

Comstock RE, Robinson HF. (1948). The components of genetic variance in population of bi-parental progenies and their use in estimating the average degree of dominance. Biometrics, 1948; 4: 254-266. Edmeades GO (2013) Progress in Achieving and Delivering Drought Tolerance in Maize-an Update. The International Service for the Acquisition of Agri-biotech Applications (ISAAA) Ithaca, NY: In Global Status of Commercialized Biotech/GM Crops: 2012, ISAAA Brief 44 .

Soil Survey Staff. Soil taxonomy: A basic system of soil classification for making and interpreting soil surveys:1999 (2nd edition). USDA-NRCS Agriculture Handbook No. 436.

Bremner JM, Mulvaney CS. Nitrogen-total. In: Page, A.L., Miller, R.H., Keeney, D.K. (Eds.). Methods of Soil Analysis. Part 2- Chemical and Microbiological Properties. Soil Science of America, Inc, Wisconsin. 1982: 595-616.

Chandler K, Lipka AE, Owens BF, Li H, Buckler ES, Rocheford T, Gore MA. Genetic Analysis of Visually Scored Orange Kernel Color in Maize. Crop Sci. 2013; 53:189-200. doi: 10.2135/cropsci2012.02.0129.

Howe JA, Tanumihardjo SA. Carotenoid-biofortified maize maintains adequate vitamin A status in Mongolian gerbils. J Nutr. 2006; 136:2562-2567. 
US Institute of Medicine. Dietary reference intakes for vitamin A, vitamin K, arsenic, boron, chromium, copper, iodine, iron, manganese, molybdenum, nickel, silicon, vanadium, and zinc. Washington, DC: The National Academies Press.2001.

Nurit E, Tiessen A, Pixley KV, Palacios-Rojas N. Reliable and inexpensive colorimetric method for determining protein-bound tryptophan in maize kernels. Journal of Agricultural and Food Chemistry 2009; 57: 7233-7238.

Villegas E, Vasal SK, Bjarnason M. Quality protein maize - what is it and how was it developed? In: Mertz, E.T. (Ed.), Quality Protein Maize. American Association of Cereal Chemists, Minnesota. U.S.A. 1992: 27-48.

Herbabdes HH, Bates LS. A modified method for rapid tryptophan analysis of maize. CIMMYT Research Bulletin No. 13. CIMMYT Mexico; 1969

SAS Institute. SAS system for windows. Release 9.4. SAS Institute Inc. Cary, North Carolina, USA; 2012.

Hallauer AR, Carena MJ, Miranda-Filho JB. Testers and combining ability. In: quantitative genetics in maize breeding: Handbook of plant breeding, lowa State University Press, Ames, 6:383-423.Harjes, C.E., T.R. Rocheford, L. Bai, T.P. Brutnell, C.B. Kandianis, S.G. Sowinski, and E.S. Buckler. 2008. Natural genetic variation in lycopene epsilon cyclase tapped for maize biofortification, Science 2010; 319:330-333.

Fonseca S, Patterson FL. Hybrid vigour in seven parental diallel cross in common wheat (Triticum aestivum L.). Crop Sci. 1968; 8: 85-8.

Wynne JC, Emery DA, Rice PH. (1970) Combining ability estimation in Arachis hypogaea L. 11 Field Performance of F1 hybrids. Crop Sci. 1970;10(6): 713 -715 .

\section{Tables}

Table 1. Mean squares of early- maturing PVA-QPM inbreds under contrasting environments at Ikenne, lle-lfe and Mokwa, 2016 - 2018.

\begin{tabular}{|c|c|c|c|c|c|c|c|c|c|c|c|}
\hline Source & DF & GY & DA & DS & ASI & PLHT & EHT & PASP & EASP & EPP & STGR \\
\hline \multicolumn{12}{|l|}{$\begin{array}{l}\text { Induced drought } \\
\text { condition }\end{array}$} \\
\hline Env & 1 & $480952.72^{\star \star}$ & $278.01^{\star \star}$ & $284.01^{\star \star}$ & 0.03 & $19881.61^{\star *}$ & $9165.73^{\star *}$ & 2.41 & 0.01 & 0.07 & $38.63^{\star \star}$ \\
\hline Rep(Env) & 2 & 11038.47 & 2.8 & 3.21 & $11.51 *$ & $294.78 *$ & 66.58 & 0.46 & 2.35 & 0.03 & $5.16^{\star \star}$ \\
\hline Block(Env*Rep) & 36 & $65311.25^{\star \star}$ & $17.35^{\star \star}$ & $21.68^{\star \star}$ & 3.93 & $330.43^{\star \star}$ & $109.03^{\star \star}$ & $1.92^{\star \star}$ & 3.60 ** & 0.06 ** & 1.71 ** \\
\hline Inbred & 69 & $131623.07^{\star \star}$ & $14.85^{\star \star}$ & $21.2^{\star \star}$ & $5.92^{\star \star}$ & $475.15^{\star \star}$ & $165.85^{\star \star}$ & $1.86^{\star \star}$ & $4.29 \star *$ & $0.08^{\star \star}$ & $2.33^{\star \star}$ \\
\hline Env*Inbred & 69 & $55852.2^{\star}$ & 3.9 & 7.15 & $4.96 *$ & 91.73 & 59.43 & 0.64 & 1.11 & 0.02 & 0.92 \\
\hline Error & 102 & 34510.18 & 6.81 & 10.62 & 3.45 & 93 & 54.13 & 0.62 & 1.07 & 0.03 & 0.64 \\
\hline Repeatability(R) & - & 0.58 & 0.74 & 0.66 & 0.16 & 0.81 & 0.64 & 0.66 & 0.74 & 0.75 & 0.61 \\
\hline \multicolumn{12}{|l|}{ Low-N condition } \\
\hline Env & 2 & $33597047.68^{\star \star}$ & 41.40 ** & $318.44^{\star \star}$ & $115.78^{\star \star}$ & $6370.30 * \star$ & $474.82^{\star \star}$ & $56.12^{\star \star}$ & $24.99 * *$ & $4.35^{\star \star}$ & $170.53^{\star *}$ \\
\hline Rep(Env) & 3 & $673976.31^{\star \star}$ & 4.03 & 3.47 & 0.05 & $1170.16^{\star \star}$ & $946.18^{* *}$ & $3.13^{\star \star}$ & 3.25 & 0.06 & 0.37 \\
\hline Block(Env*Rep) & 54 & $302824.7^{\star \star}$ & 2.15 & 2.54 & 0.96 & $277.44^{\star \star}$ & $108.01^{*}$ & 1.61 ** & $2.60 \star *$ & $0.04 *$ & $0.72^{*}$ \\
\hline Inbred & 69 & $526260.25^{\star \star}$ & $9.38 * \star$ & $13.03^{\star \star}$ & $4.75^{\star \star}$ & $749.38 * \star$ & $186.99 * \star$ & $1.28^{\star \star}$ & $3.18^{\star \star}$ & $0.11^{\star \star}$ & $1.57 \star \star$ \\
\hline Env*Inbred & 138 & 307000.74 ** & $3.49 * *$ & $5.88^{\star \star}$ & 3.01 ** & $295.84^{\star *}$ & 80.45 & $1.05^{\star \star}$ & $3.14^{\star \star}$ & $0.08^{\star *}$ & $0.94 * *$ \\
\hline Error & 153 & 143160.7 & 1.85 & 2.45 & 0.83 & 110.53 & 70.74 & 0.62 & 1.36 & 0.03 & 0.50 \\
\hline Repeatability(R) & - & 0.42 & 0.63 & 0.55 & 0.37 & 0.61 & 0.57 & 0.18 & 0.20 & 0.27 & 0.40 \\
\hline
\end{tabular}

${ }^{*}, * *=$ Significant at 0.05 and 0.01 probability levels, respectively; Env = environment; Rep=replication; GY = Grain yield (kg ha-1); DA= days to $50 \%$ anthesis; DS = days to $50 \%$ silking; $\mathrm{ASI}=$ anthesis-silking interval; $\mathrm{PLHT}=$ plant height $(\mathrm{cm})$; EHT = ear height $(\mathrm{cm})$; PASP = plant aspect (1-9); EASP = ear aspect (1-9); EPP =ears per plant; STGR= stay-green characteristic (1-9).

Table 2. Mean squares of early- maturing PVA-QPM inbreds under optimal and across research conditions, 2016-2017. 


\begin{tabular}{|c|c|c|c|c|c|c|c|c|c|c|c|}
\hline Source & DF & GY & DA & DS & ASI & PLHT & EHT & PASP & EASP & EPP & DF \\
\hline \multicolumn{12}{|l|}{$\begin{array}{l}\text { Optimal } \\
\text { conditions }\end{array}$} \\
\hline Env & 2 & $134313818.6^{\star \star}$ & $101.29 * \star$ & $362.52^{\star \star}$ & $81.52^{\star \star}$ & $45577.87^{\star \star}$ & 20840.08 *夫 & 118.98 ** & $173.25^{\star \star}$ & $7.55^{\star \star}$ & - \\
\hline Rep(Env) & 3 & 21773.4 & 0.54 & 1.57 & 0.93 & $694.99 * \star$ & $420.69 * *$ & $10.25^{\star \star}$ & $9.62^{\star \star}$ & $0.13^{\star *}$ & - \\
\hline Block(Env*Rep) & 54 & 103579.7 & $5.55^{\star \star}$ & $7.96 * \star$ & $1.00 \star \star$ & $311.75^{\star \star}$ & $118.27^{\star \star}$ & $1.33^{\star}$ & 1.31 & $0.05^{\star}$ & - \\
\hline Inbred & 69 & $768236.7 * \star$ & $14.95^{\star \star}$ & $18.25^{\star \star}$ & $1.43^{\star \star}$ & $633.41^{\star \star}$ & $220.14^{\star \star}$ & $1.68^{\star \star}$ & $2.53^{\star \star}$ & $0.06^{* *}$ & - \\
\hline Env*Inbred & 138 & $490480.8^{\star \star}$ & 2.18 & $3.05^{\star}$ & $1.02^{\star \star}$ & 141.65 & $85.31^{*}$ & $1.12^{\star}$ & 1.22 & $0.04 *$ & - \\
\hline Error & 153 & 73194.1 & 1.86 & 2.26 & 0.58 & 111.5689 & 60.91 & 0.83 & 1.03 & 0.03 & - \\
\hline Repeatability(R) & - & 0.58 & 0.85 & 0.83 & 0.29 & 0.63 & 0.61 & 0.33 & 0.52 & 0.33 & - \\
\hline \multicolumn{12}{|l|}{$\begin{array}{l}\text { Across research } \\
\text { conditions }\end{array}$} \\
\hline Env & 7 & $82217326.1^{\star \star}$ & $191.49 * \star$ & 1051.91 ** & $404.54 * \star$ & 64747.46 ** & $10398.83^{\star \star}$ & $98.33^{\star \star}$ & $221.51^{\star \star}$ & $9.13^{\star \star}$ & 4 \\
\hline Rcond & 2 & $119609298.8^{\star *}$ & $405.11^{\star \star}$ & $2800.80 * *$ & $1228.83^{\star \star}$ & $164727.14^{\star \star}$ & $10498.15^{\star \star}$ & $167.84^{\star \star}$ & $577.05^{\star \star}$ & $20.05^{\star \star}$ & 1 \\
\hline Rep(Env) & 8 & $263665.7^{\star \star}$ & 2.16 & 2.96 & $3.26^{\star}$ & $773.13^{\star \star}$ & $529.22 * \star$ & $5.13^{\star \star}$ & 5.41 ** & $0.08^{\star \star}$ & 5 \\
\hline Block(Env*Rep) & 144 & $168729.5^{\star \star}$ & $7.24 \star \star$ & $9.33^{\star *}$ & 1.7 & $303.55^{\star \star}$ & $112.11^{\star \star}$ & $1.58 * *$ & $2.37 \star \star$ & $0.05^{\star \star}$ & 90 \\
\hline Inbred & 69 & $661182.5^{\star \star}$ & $31.09 * *$ & $37.33^{\star \star}$ & $5.02^{\star \star}$ & $1477.70 * \star$ & $432.19 * \star$ & $1.95^{\star \star}$ & $4.30 * *$ & $0.08^{* *}$ & 69 \\
\hline Rcond*Inbred & 138 & 399198.2 & 4.94 & 7.5 & $3.64^{\star \star}$ & 209.15 & 72.7 & 1.46 & $2.85^{\star}$ & 0.08 & 69 \\
\hline Env*Inbred & 483 & $346564.9 \star \star$ & 3.54 & $5.66^{\star \star}$ & $2.96^{\star \star}$ & $195.14^{\star \star}$ & $75.56^{\star}$ & $1.12^{\star \star}$ & $2.24 \star \star$ & $0.06^{\star \star}$ & 276 \\
\hline Error & 408 & 89760.6 & 3.17 & 4.37 & 1.45 & 106.54 & 62.9 & 0.7 & 1.16 & 0.03 & 255 \\
\hline Repeatability(R) & - & 0.48 & 0.89 & 0.85 & 0.41 & 0.87 & 0.83 & 0.43 & 0.48 & 0.25 & - \\
\hline
\end{tabular}

${ }^{*}, * *=$ Significant at 0.05 and 0.01 probability levels, respectively; Env = environment; Rep=replication; GY = Grain yield (kg ha-1); DA= days to 50\% anthesis; DS = days to 50\% silking; $\mathrm{ASI}=$ anthesis-silking interval; $\mathrm{PLHT}=$ plant height $(\mathrm{cm}) ; \mathrm{EHT}=$ ear height $(\mathrm{cm}) ; \mathrm{PASP}=$ plant aspect $(1-9) ; \mathrm{EASP}=$ ear aspect $(1-9)$; EPP =ears per plant; STGR= stay-green characteristic (1-9).

Table 3. Performance of early PVA-QPM inbreds (best 15 and worst 10) including checks under contrasting environments. 


\begin{tabular}{|c|c|c|c|c|c|c|c|c|c|c|c|c|c|}
\hline & $\begin{array}{l}\text { Grain } \\
\text { Yield (kg } \\
\text { ha-1) }\end{array}$ & & & & $\begin{array}{l}\text { Yield } \\
\text { Reduction } \\
\text { (\%) }\end{array}$ & & & ASI & & & STGR & & $\begin{array}{l}\text { M.I } \\
\text { Across }\end{array}$ \\
\hline Inbred & Drought & Low-N & Optimal & $\begin{array}{l}\text { Across } \\
\text { Env }\end{array}$ & Drought & Low- & $\begin{array}{l}\text { Across } \\
\text { Stress }\end{array}$ & Drought & Low- & Optimal & Drought & $\begin{array}{l}\text { Low- } \\
\mathbf{N}\end{array}$ & Stress \\
\hline $\begin{array}{l}\text { TZEIORQ } \\
12\end{array}$ & 307.29 & 1651.55 & 1882 & 1280.34 & 83.67 & 12.25 & 39.99 & 3.71 & 0.02 & 0.59 & 4.44 & 3.48 & 9.90 \\
\hline $\begin{array}{l}\text { TZEIORQ } \\
48\end{array}$ & 321.02 & 1617.67 & 1773 & 1237.36 & 81.90 & 8.78 & 36.88 & 3.64 & 0.29 & 0.56 & 4.69 & 3.94 & 8.26 \\
\hline $\begin{array}{l}\text { TZEIORQ } \\
6\end{array}$ & 701.74 & 994.21 & 1180 & 958.51 & 40.51 & 15.71 & 28.11 & 3.75 & -0.01 & 0.31 & 3.68 & 4.16 & 8.26 \\
\hline $\begin{array}{l}\text { TZEIORQ } \\
8\end{array}$ & 895.12 & 1051.06 & 1194 & 1046.57 & 25.00 & 11.94 & 18.47 & 2.65 & 0.96 & 1.03 & 3.25 & 4.93 & 8.01 \\
\hline $\begin{array}{l}\text { TZEIORQ } \\
37\end{array}$ & 462.79 & 1329.34 & 1803 & 1198.38 & 74.33 & 26.27 & 50.30 & 3.97 & 0.73 & 0.73 & 3.36 & 3.32 & 7.97 \\
\hline $\begin{array}{l}\text { TZEIORQ } \\
27\end{array}$ & 701.48 & 1320.87 & 1900 & 1307.35 & 63.07 & 30.47 & 46.77 & 3.91 & 0.27 & 0.40 & 4.89 & 3.08 & 7.50 \\
\hline $\begin{array}{l}\text { TZEIORQ } \\
5\end{array}$ & 518.62 & 1023.99 & 1194 & 912.10 & 56.55 & 14.22 & 35.38 & 1.69 & 0.17 & 0.39 & 3.56 & 4.73 & 7.03 \\
\hline $\begin{array}{l}\text { TZEIORQ } \\
9\end{array}$ & 523.25 & 979.67 & 1765 & 1089.33 & 70.36 & 44.50 & 57.43 & 3.22 & 1.19 & 0.64 & 4.10 & 4.26 & 6.20 \\
\hline $\begin{array}{l}\text { TZEIORQ } \\
28\end{array}$ & 567.56 & 1297.60 & 2075 & 1313.43 & 72.65 & 37.47 & 55.06 & 3.57 & 0.92 & 0.12 & 4.22 & 4.41 & 5.70 \\
\hline $\begin{array}{l}\text { C6-TZEI } \\
24\end{array}$ & 349.98 & 1437.46 & 1920 & 1235.92 & 81.77 & 25.14 & 53.46 & 6.60 & 0.55 & 0.33 & 4.88 & 2.86 & 5.17 \\
\hline $\begin{array}{l}\text { TZEIORQ } \\
17\end{array}$ & 270.38 & 1175.9 & 1351 & 932.35 & 79.98 & 12.95 & 46.46 & 3.30 & 0.52 & 0.24 & 4.61 & 3.34 & 4.79 \\
\hline $\begin{array}{l}\text { TZEIORQ } \\
40\end{array}$ & 227.28 & 1292.32 & 1457 & 992.10 & 84.40 & 11.28 & 47.84 & 3.23 & 0.66 & 0.7 & 4.70 & 3.78 & 4.69 \\
\hline $\begin{array}{l}\text { TZEIORQ } \\
26\end{array}$ & 342.42 & 1096.03 & 1310 & 916.11 & 73.86 & 16.33 & 45.09 & 3.09 & 0.06 & 0.37 & 3.70 & 4.75 & 4.65 \\
\hline $\begin{array}{l}\text { C5-TZEI } \\
129\end{array}$ & 336.09 & 1273.23 & 1843 & 1150.85 & 81.77 & 30.92 & 56.34 & 4.47 & 0.42 & 0.63 & 4.59 & 3.22 & 4.57 \\
\hline $\begin{array}{l}\text { TZEIORQ } \\
60\end{array}$ & 283.41 & 917.45 & 1149 & 783.23 & 75.33 & 20.14 & 47.74 & 4.19 & 1.01 & 1.23 & 2.94 & 2.82 & 3.47 \\
\hline $\begin{array}{l}\text { TZEIORQ } \\
65\end{array}$ & 418.76 & 1160.89 & 2034 & 1204.48 & 79.41 & 42.92 & 61.16 & 3.36 & 0.48 & 0.96 & 4.21 & 3.79 & 1.87 \\
\hline $\begin{array}{l}\text { TZEIORQ } \\
24\end{array}$ & 399.10 & 401.64 & 519 & 439.75 & 23.03 & 22.54 & 22.78 & 3.57 & -0.26 & 0.15 & 3.87 & 4.77 & 1.55 \\
\hline $\begin{array}{l}\text { TZEIORQ } \\
29\end{array}$ & 297.27 & 857.81 & 1139 & 764.66 & 73.90 & 24.68 & 49.29 & 5.78 & 0.90 & 1.23 & 4.27 & 3.34 & -0.20 \\
\hline $\begin{array}{l}\text { TZEIORQ } \\
59\end{array}$ & 147.54 & 769.54 & 2086 & 1001.16 & 92.93 & 63.12 & 78.02 & 4.25 & 0.55 & 1.50 & 4.56 & 2.90 & -0.67 \\
\hline $\begin{array}{l}\text { TZEIORQ } \\
11\end{array}$ & 122.10 & 844.8 & 2189 & 1051.84 & 94.42 & 61.40 & 77.91 & 4.57 & 1.50 & 0.10 & 5.62 & 3.96 & -1.74 \\
\hline $\begin{array}{l}\text { TZEIORQ } \\
20\end{array}$ & 364.47 & 571.58 & 1055 & 663.78 & 65.46 & 45.84 & 55.65 & 3.85 & 0.28 & 1.16 & 4.14 & 4.63 & -3.59 \\
\hline $\begin{array}{l}\text { TZEIORQ } \\
13\end{array}$ & 191.53 & 1138.79 & 2171 & 1167.03 & 91.18 & 47.54 & 69.36 & 4.67 & 2.43 & 0.07 & 6.25 & 4.03 & -3.85 \\
\hline $\begin{array}{l}\text { TZEIORQ } \\
55\end{array}$ & 272.98 & 1227.95 & 1427 & 976.11 & 80.88 & 13.97 & 47.42 & 5.42 & 0.01 & 1.46 & 4.78 & 4.23 & -4.45 \\
\hline $\begin{array}{l}\text { C4- } \\
\text { TZEQI } 82\end{array}$ & 109.31 & 853.60 & 1342 & 768.34 & 91.86 & 36.40 & 64.13 & 6.15 & 2.26 & 1.94 & 3.54 & 3.86 & -5.21 \\
\hline $\begin{array}{l}\text { TZEIORQ } \\
2\end{array}$ & 112.67 & 606.95 & 1462 & 699.25 & 92.29 & 58.49 & 75.39 & 3.27 & 1.24 & 1.02 & 4.54 & 3.83 & -5.52 \\
\hline $\begin{array}{l}\text { TZEIORQ } \\
52\end{array}$ & 119.43 & 599.08 & 1548 & 755.48 & 92.28 & 61.30 & 76.79 & 4.29 & 0.69 & 0.56 & 4.97 & 4.46 & -7.26 \\
\hline $\begin{array}{l}\text { C2 - } \\
\text { TZEQI } 91\end{array}$ & 144.89 & 986.91 & 1685 & 938.78 & 91.40 & 41.41 & 66.41 & 5.60 & 2.22 & 0.05 & 5.45 & 4.05 & -7.49 \\
\hline
\end{tabular}




\begin{tabular}{|c|c|c|c|c|c|c|c|c|c|c|c|c|c|}
\hline $\begin{array}{l}\text { TZEIORQ } \\
46\end{array}$ & 106.55 & 458.35 & 1396 & 653.74 & 92.37 & 67.17 & 79.77 & 4.72 & 2.03 & 0.54 & 6.65 & 5.13 & -10.89 \\
\hline $\begin{array}{l}\text { TZEIORQ } \\
41\end{array}$ & 100.00 & 842.94 & 1191 & 711.14 & 91.60 & 29.19 & 60.40 & 6.55 & 2.56 & 0.79 & 6.07 & 4.31 & -11.82 \\
\hline $\begin{array}{l}\text { C1- } \\
\text { TZEQI } 85\end{array}$ & 104.62 & 297.96 & 1610 & 670.77 & 93.50 & 81.49 & 87.50 & 6.14 & 3.34 & 1.56 & 5.15 & 3.83 & -13.22 \\
\hline $\begin{array}{l}\text { C3- } \\
\text { TZEQI } 74\end{array}$ & 123.98 & 298.79 & 760 & 394.18 & 83.68 & 60.67 & 72.18 & 4.05 & 5.21 & 1.21 & 4.26 & 4.00 & -13.26 \\
\hline Mean & 321 & 980 & 1529 & 942 & 76.62 & 34.73 & 55.68 & 4.27 & 1.07 & 0.73 & 4.51 & 3.94 & \\
\hline Sed & 105.21 & 175.23 & 125. & 84.88 & - & - & - & 1.05 & 0.42 & 0.35 & 0.45 & 0.33 & \\
\hline
\end{tabular}

$\mathrm{C} 1$ to $\mathrm{C} 6$ = Checks 1 to 6 respectively; Env= environment; $\mathrm{ASI}=$ anthesis silking interval; STGR= stay green characteristics; M. I= multiple trait base index

Table 4. Carotenoid and tryptophan contents, and reactions of selected PVA-QPM inbreds to drought and low-N environments.

\begin{tabular}{|c|c|c|c|c|c|c|c|c|c|c|c|c|}
\hline & $\begin{array}{l}\text { Carotenoids } \S(\mu \mathrm{g} \mathrm{g}-1 \mathrm{dry} \\
\text { weight) }\end{array}$ & & & & & & & & $\begin{array}{l}\text { Reaction to drought } \\
\text { and low-N }\end{array}$ & & & \\
\hline Inbred lines & Lut & Zeax & $\begin{array}{l}\beta- \\
\text { cryp }\end{array}$ & $\begin{array}{l}a- \\
\text { caro }\end{array}$ & $\begin{array}{l}\beta- \\
\text { caro }\end{array}$ & 囚PVA & Tcaro & $\begin{array}{l}\text { Tryp } \\
\text { (\%) }\end{array}$ & Kern-col & $\begin{array}{l}\text { Drought } \\
\mathrm{BI}\end{array}$ & $\begin{array}{l}\text { Low- } \\
\text { NBI }\end{array}$ & MI \\
\hline TZEIORQ 55 & 19.19 & 21.49 & 6.61 & 1.71 & 11.23 & 15.38 & 60.22 & 0.096 & 8.0 & -1.00 & -7.61 & -6.49 \\
\hline TZEIORQ 29 & 27.07 & 6.31 & 6.11 & 2.10 & 7.69 & 12.10 & 49.28 & 0.119 & 9.0 & -2.02 & 1.57 & -0.2 \\
\hline TZEIORQ 20 & 15.04 & 21.70 & 3.84 & 1.31 & 5.78 & 8.36 & 47.67 & 0.087 & 8.0 & 1.93 & -5.52 & -3.59 \\
\hline TZEIORQ 42 & 10.63 & 23.19 & 4.99 & 1.27 & 5.21 & 8.34 & 45.30 & 0.124 & 8.0 & -2.06 & 4.50 & 2.20 \\
\hline TZEIORQ 13 & 3.68 & 10.11 & 1.40 & 0.54 & 6.72 & 7.70 & 22.46 & 0.120 & 7.0 & -5.25 & 1.18 & -3.85 \\
\hline TZEIORQ 24 & 7.89 & 20.86 & 3.71 & 1.16 & 4.17 & 6.60 & 37.79 & 0.104 & 10.0 & 8.44 & -2.85 & 1.55 \\
\hline TZEIORQ 59 & 25.79 & 15.17 & 2.11 & 1.00 & 4.64 & 6.19 & 48.71 & 0.121 & 8.0 & -1.31 & -0.04 & -0.67 \\
\hline TZEIORQ 40 & 13.30 & 16.97 & 1.53 & 0.44 & 4.62 & 5.61 & 36.86 & 0.065 & 9.0 & 4.05 & 2.78 & 4.69 \\
\hline TZEIORQ 7 & 10.43 & 19.33 & 3.36 & 1.11 & 3.37 & 5.61 & 37.61 & 0.101 & 8.0 & 11.25 & 2.35 & 7.79 \\
\hline TZEIORQ 6 & 10.30 & 19.07 & 3.18 & 0.94 & 3.44 & 5.50 & 36.93 & 0.118 & 7.0 & 12.46 & 2.47 & 8.26 \\
\hline TZEIORQ 26 & 9.62 & 18.04 & 2.88 & 0.89 & 3.40 & 5.28 & 34.82 & 0.102 & 7.0 & 5.51 & 1.90 & 4.65 \\
\hline TZEIORQ 5 & 9.78 & 18.06 & 2.76 & 0.89 & 3.35 & 5.18 & 34.85 & 0.110 & 8.0 & 12.01 & 0.59 & 7.03 \\
\hline TZEIORQ 43 & 16.20 & 18.01 & 1.79 & 0.45 & 3.99 & 5.11 & 40.44 & 0.113 & 8.0 & -3.66 & 0.99 & -1.60 \\
\hline TZEIORQ 45 & 18.77 & 16.27 & 1.46 & 0.99 & 3.88 & 5.10 & 41.36 & 0.106 & 8.0 & -4.52 & 5.62 & 0.25 \\
\hline TZEIORQ 23 & 9.52 & 18.58 & 2.82 & 0.91 & 3.20 & 5.06 & 35.03 & 0.091 & 7.0 & 6.97 & -3.02 & 1.52 \\
\hline TZEIORQ 44 & 14.34 & 16.53 & 1.68 & 0.50 & 3.80 & 4.89 & 36.85 & 0.089 & 8.0 & -2.35 & -1.80 & -2.81 \\
\hline TZEIORQ 2 & 4.89 & 16.58 & 1.83 & 0.50 & 2.65 & 3.82 & 26.44 & 0.102 & 7.0 & -2.93 & -5.79 & -5.52 \\
\hline TZEIORQ 47 & 17.75 & 13.65 & 1.15 & 1.00 & 2.48 & 3.55 & 36.03 & 0.056 & 7.0 & 0.34 & -2.33 & -2.14 \\
\hline TZEIORQ 48 & 8.84 & 17.23 & 1.56 & 1.00 & 2.18 & 3.47 & 30.83 & 0.115 & 7.0 & 1.70 & 9.03 & 8.26 \\
\hline †OBATANPA & - & - & - & - & - & - & - & 0.198 & - & - & - & - \\
\hline Sed & 2.19 & 2.44 & 0.54 & 0.43 & 0.27 & 0.44 & 3.29 & 0.008 & 1.12 & - & - & - \\
\hline Min. & 3.68 & 6.31 & 1.15 & 0.45 & 2.18 & 3.47 & 22.46 & 0.056 & 7.0 & -5.25 & -7.61 & -6.49 \\
\hline Max. & 27.07 & 23.19 & 6.61 & 2.10 & 11.23 & 15.38 & 60.22 & 0.198 & 10.0 & 12.46 & 9.03 & 8.26 \\
\hline Mean & 13.32 & 17.22 & 2.88 & 0.99 & 4.52 & 6.47 & 38.92 & 0.110 & 7.84 & - & - & - \\
\hline
\end{tabular}

$\S$ Carotenoids are abbreviated as Lut= iutein; Zeax= zeaxanthin; $\beta$-cryp= $\beta$-cryptoxanthin; $\alpha$-caro= alpha-carotene; $\beta$-caor= $\beta$-carotene; $\mathrm{ZPVA}=$ provitamin $A$; Tcaro= total carotenoids; Kern-col= kernel colour (scored on a scale of 1 to $12,1=$ pale yellow, $12=$ darkest orange); Tryp= tryptophan; $B . I=$ base index; $\mathrm{Ml}=$ multiple trait base index, with positive value= Tolerance, and negative value= Susceptibility; $\mathbf{\dagger =}$ QPM standard check. 
Table 5. Phenotypic correlation co-efficients among traits of selected provitamin A quality protein maize inbred lines

\begin{tabular}{|c|c|c|c|c|c|c|c|c|c|}
\hline Trait & XPVA & $\beta$-сryp & a-caro & $\beta$-caro & Tcaro & Kern-col & Lut & Zeax & Tryp \\
\hline$\beta$-cryp & $0.75^{\star \star \star}$ & & & & & & & & \\
\hline a-caro & $0.67 \star \star$ & $0.77^{\star \star \star \star}$ & & & & & & & \\
\hline$\beta$-caro & $0.93^{\star \star \star}$ & $0.58^{\star}$ & $0.54^{*}$ & & & & & & \\
\hline Tcar & $0.73^{\star \star}$ & $0.69 \star \star$ & $0.74^{* *}$ & $0.75^{\star \star \star}$ & & & & & \\
\hline Kern-col & $0.52^{*}$ & 0.37 & 0.32 & $0.55^{\star}$ & $0.63^{\star \star}$ & & & & \\
\hline Lut & 0.19 & 0.07 & 0.24 & 0.32 & $0.62^{\star \star}$ & $0.43^{\star}$ & & & \\
\hline Zeax & 0.23 & $0.55^{\star}$ & 0.28 & 0.05 & 0.25 & 0.11 & -0.24 & & \\
\hline Tryp & 0.20 & 0.27 & 0.20 & 0.14 & 0.04 & -0.02 & -0.04 & -0.07 & \\
\hline GY & -0.39 & $-0.73^{\star \star}$ & -0.41 & -0.16 & -0.32 & -0.34 & 0.05 & $-0.64^{\star \star}$ & 0.08 \\
\hline
\end{tabular}

$* * *, * *, *=$ Significant at $P<0.001,0.01$ and 0.05 respectively; Carotenoids are abbreviated as $\mathbb{Q P V A}=$ provitamin $A ; \beta$-cryp $=\beta$-cryptoxanthin; $a$-caro= alphacarotene; $\beta$-caor $=\beta$-carotene; Tcaro= Total carotenoid; Kern-col= Kernel colour (scored on a scale of 1 to $12,1=$ pale yellow, $12=$ darkest orange) Lut= Lutein; Zeax= Zeaxanthin; Tryp= Tryptophan; GY= grain yield across drought, low-N and optimal environments.

Table 6. Grain yield performance of early PVA-QPM hybrids under contrasting environments for two years in Nigeria. 


\begin{tabular}{|c|c|c|c|c|c|c|}
\hline Hybrid & $\begin{array}{l}\text { Drought } \\
\text { conditions }\end{array}$ & $\begin{array}{l}\text { Low-N } \\
\text { conditions }\end{array}$ & $\begin{array}{l}\text { Across stress } \\
\text { conditions }\end{array}$ & $\begin{array}{l}\text { Optimal } \\
\text { conditions }\end{array}$ & $\begin{array}{l}\text { \%YRD across } \\
\text { stress }\end{array}$ & $\begin{array}{l}\text { Ml across } \\
\text { stress }\end{array}$ \\
\hline TZEIORQ $40 \times$ TZEIORQ 26 & 4853 & 4155 & 4388 & 5641 & 22.21 & 8.09 \\
\hline TZEIORQ 26 x TZEIORQ 47 & 5085 & 4160 & 4468 & 5834 & 23.41 & 6.71 \\
\hline TZEIORQ $42 \times$ TZEIORQ 20 & 3908 & 4584 & 4359 & 5286 & 17.55 & 6.67 \\
\hline TZEIORQ $24 \times$ TZEIORQ 41 & 4499 & 3950 & 4134 & 5776 & 28.42 & 6.66 \\
\hline TZEIORQ $20 \times$ TZEIORQ 45 & 5012 & 3961 & 4312 & 5396 & 20.09 & 6.57 \\
\hline TZEIORQ 29 x TZEIORQ 43 & 2866 & 5055 & 4474 & 5278 & 15.23 & 6.29 \\
\hline TZEIORQ 48 x TZEIORQ 43 & 3519 & 4694 & 4302 & 5322 & 19.17 & 6.05 \\
\hline TZEIORQ 43 x TZEIORQ 5 & 3886 & 4359 & 4201 & 5862 & 28.32 & 5.87 \\
\hline TZEIORQ 6 x TZEIORQ 29 & 4728 & 3322 & 3790 & 5042 & 24.82 & 5.45 \\
\hline TZEIORQ 29 x TZEIORQ 24 & 5500 & 3792 & 4362 & 5413 & 19.42 & 5.29 \\
\hline Check 2 - TZEI 124 x TZEI 25 & 3607 & 3690 & 3663 & 5895 & 37.87 & 5.19 \\
\hline TZEIORQ $26 \times$ TZEIORQ 13 & 4160 & 4384 & 4309 & 5795 & 25.65 & 5.02 \\
\hline TZEIORQ $44 \times$ TZEIORQ 29 & 3214 & 3920 & 3684 & 5691 & 35.25 & 4.72 \\
\hline TZEIORQ 43 x TZEIORQ 26 & 4557 & 4030 & 4205 & 5379 & 21.82 & 4.54 \\
\hline TZEIORQ 26 x TZEQI 82 & 4030 & 3935 & 3967 & 6013 & 34.03 & 4.45 \\
\hline TZEIORQ $45 \times$ TZEIORQ 24 & 4826 & 4017 & 4287 & 4929 & 13.03 & 4.14 \\
\hline $\begin{array}{l}\text { Check } 1 \text { - TZEIOR } 127 \text { x } \\
\text { TZEIOR } 57\end{array}$ & 2749 & 3805 & 3453 & 5083 & 32.07 & 4.13 \\
\hline TZEIORQ 6 × TZEIORQ 45 & 4773 & 3615 & 4001 & 5372 & 25.53 & 4.12 \\
\hline TZEIORQ $29 \times$ TZEIORQ 40 & 3680 & 3784 & 3749 & 5252 & 28.61 & 3.97 \\
\hline TZEIORQ 5 x TZEIORQ 13 & 4311 & 3749 & 3925 & 5525 & 28.97 & 3.91 \\
\hline Sed & 522 & 356 & 295 & 344 & - & - \\
\hline Min. & 2749 & 3322 & 3453 & 5042 & 13.03 & 3.91 \\
\hline Max. & 5500 & 5055 & 4474 & 6013 & 37.87 & 8.09 \\
\hline Mean & 4188 & 4048 & 4102 & 5489 & 25.07 & 5.39 \\
\hline
\end{tabular}

$\mathrm{Ml}=$ multiple trait base index

Table 7. Correlation coefficients of selected early PVA-QPM parents and hybrids under contrasting environments in Nigeria, 2017-2018 


\begin{tabular}{|c|c|c|c|c|c|c|c|c|}
\hline & $\begin{array}{l}\text { Correlation coefficient } \\
\text { (r) }\end{array}$ & & & & $\begin{array}{l}\text { Average heterosis } \\
(\%)\end{array}$ & & & \\
\hline Trait & Drought & Low-N & Optimal & $\begin{array}{l}\text { Across } \\
\text { Env }\end{array}$ & Drought & Low N & Optimal & $\begin{array}{l}\text { Across } \\
\text { Env }\end{array}$ \\
\hline Grain yield (kgha-1) & $0.30 \star \star$ & $0.23^{\star}$ & $0.21 *$ & $0.26^{*}$ & 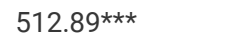 & $236.61 * \star$ & $234.58^{\star \star}$ & $314.63^{\star *}$ \\
\hline Days to $50 \%$ anthesis (days) & 0.06 & $0.27 * \star$ & $0.29 \star \star$ & $0.29 * \star$ & $-2.63^{*}$ & $-5.20 * \star$ & $-5.49 * \star$ & $-5.47 \star \star$ \\
\hline Days to $50 \%$ silking (days) & 0.04 & $0.30 * \star$ & $0.29 * \star$ & $0.29 * \star$ & $-5.23^{\star \star}$ & $-5.53^{\star \star}$ & $-5.40 * \star$ & $-6.25^{\star \star}$ \\
\hline Anthesis silking interval & 0.02 & 0.14 & 0.04 & 0.11 & $-38.90 \star \star$ & -102.07 & 1.76 & -35.62 \\
\hline Plant height (cm) & $0.45^{\star \star}$ & 0.51 ** & $0.46 * \star$ & $0.50 \star \star$ & $114.05^{\star \star}$ & $28.37 * \star$ & $35.02^{\star \star}$ & $44.60 * \star$ \\
\hline Ear height (cm) & $0.34 \star *$ & $0.23^{\star}$ & 0.16 & $0.22^{\star}$ & $137.19 * *$ & $52.54 * \star$ & $58.98 * \star$ & $71.26^{\star \star}$ \\
\hline Root lodging & 0.08 & 0.07 & 0.13 & 0.11 & 22.02 & 187.42 & 160.88 & 28.63 \\
\hline Stalk lodging & 0.07 & 0.04 & 0.01 & 0.03 & 0.424 & 10.38 & 34.95 & 16.1 \\
\hline Husk cover & 0.12 & 0.09 & 0.17 & 0.01 & 11.88 & $30.45^{\star}$ & 31.59 & 10.87 \\
\hline Plant aspect (1-9)a & $0.24^{\star}$ & $0.29 * *$ & 0.14 & 0.31 ** & 10.07 & 11.91 & $28.65^{\star \star}$ & 11 \\
\hline Ear aspect (1-9)b & $0.45^{\star \star}$ & $0.33^{* *}$ & $0.24^{\star}$ & $0.32^{* *}$ & $24.78^{\star \star \star}$ & -0.45 & 15.38 & -4.44 \\
\hline $\begin{array}{l}\text { Number of ears per plant } \\
\text { (No.) }\end{array}$ & $0.26^{*}$ & 0.06 & 0.07 & 0.11 & $214.51 * \star \star$ & 18.41 & 12.27 & $31.28^{*}$ \\
\hline $\begin{array}{l}\text { Stay green characteristic (1- } \\
\text { 9)c }\end{array}$ & $0.23^{*}$ & 0.34 ** & - & $0.21^{\star}$ & -9.81 & -6.11 & - & -9.45 \\
\hline \multicolumn{9}{|c|}{ *, ** Significant at 0.05 and 0.01 probability levels, respectively, Env= environment. } \\
\hline \multicolumn{9}{|c|}{ a Plant aspect (on a scale of 1-9), where $1=$ excellent overall phenotypic appeal and $9=$ poor overall phenotypic appeal. } \\
\hline
\end{tabular}

\section{Supplementary Files}

This is a list of supplementary files associated with this preprint. Click to download.

- supplement1.doc

- supplement2.doc

- supplement3.doc 